Crime, Histoire \& Sociétés / Crime, History \& Societies

Vol. 21, $n^{\circ} 2$ | 2017

L'histoire de la criminalité et de la justice pénale : propositions de recherche pour le $21^{\mathrm{e}}$ siècle

\title{
Future Directions in African Crime and Criminal Justice History
}

Stacey Hynd

\section{CpenEdition}

\section{Journals}

Electronic version

URL: http://journals.openedition.org/chs/1888

DOI: $10.4000 /$ chs. 1888

ISSN: 1663-4837

\section{Publisher}

Librairie Droz

\section{Printed version}

Date of publication: 31 December 2017

Number of pages: 205-218

ISSN: $1422-0857$

Electronic reference

Stacey Hynd, "Future Directions in African Crime and Criminal Justice History", Crime, Histoire \& Sociétés / Crime, History \& Societies [Online], Vol. 21, n² | 2017, Online since 19 July 2020, connection on 13 January 2021. URL: http://journals.openedition.org/chs/1888; DOI: https://doi.org/10.4000/ chs. 1888 


\title{
Future Directions in African Crime and Criminal Justice History
}

\author{
Stacey Hynd \\ "One slaughters a beast and then throws feed to his brother. One does not do \\ that to a human being"1.
}

\begin{abstract}
$\mathrm{T}$ This is what the history of crime and law in Africa should do, and has been striving to do: to analyse what it means to be human, to live a life as part of a given community under often extraordinarily difficult conditions, and to investigate what happens when the social and legal boundaries establishing appropriate membership of that community are violated. Jonny Steinberg's account of one young Somali's journey from Mogadishu, through the Somali civil war, to becoming a refugee and trying to establish a new life in post-apartheid South Africa is part of a vibrant new generation of scholarship on crime in Africa, one that explores the lived realities of ordinary Africans and the laws that shape, and often fail to protect, their existence. Steinberg recounts Asad's struggle to survive and provide for his family as part of a marginalized refugee population in the face of xenophobia, criminal gangs, and the failure of the police to investigate the murder of his uncle, leaving Asad railing against the injustice of a society that sees him potentially facing his uncle's killers every day in the community and knowing that one day his life too may be ended $^{2}$. This article will briefly sketch the key developments in African criminal and criminal justice history since the 1980s, looking at colonial, postcolonial and contemporary developments, before highlighting productive areas and methods for future research. It should be noted that a lot of the most exciting research is not being done within traditional "criminal history" itself, nor is it even exclusively focused on issues of crime, justice and punishment: more often, these issues are used as a methodological lens by scholars to explore related issues of power, mass violence, injustice, and inequality.

The field of African crime and criminal justice history emerged in the 1980s. Prior to this the field was dominated by colonial ethnographic studies of "customary law", legal anthropology, and studies by metropolitan-educated African elites ${ }^{3}$. Revisionist histories from the 1980s onwards however showed that "custom" was
\end{abstract}

Jonny Steinberg, A man of good hope: one man's extraordinary journey from Mogadishu to Cape Town (2016a, p.230).

2 Steinberg (2016a).

3 See Danquah (1928); Rattray (1929); Kenyatta (1938); Gluckman (1955).

Crime, Histoire \& Sociétés / Crime, History \& Societies 2017, vol. 21, n 2, pp. 205-218. 
often a modern "(re-)invention of tradition". Instead they highlighted the legal pluralism that shape colonial courts and explored how law served as a cornerstone of colonial rule, establishing - and sometimes restraining - its power, and how Africans exerted agency in negotiating colonial legal arenas ${ }^{5}$. Crime in Africa was first studied as a form of resistance against colonization and the widespread criminalization of native life and labour ${ }^{6}$, but more recently scholars have been analysing criminality as a lens through which to understand tensions within African communities and the socio-cultural changes wrought by colonialism, as in studies of liquor controls and drunkenness $^{7}$, prostitution ${ }^{8}$, madness and criminal insanity ${ }^{9}$, as well as murder ${ }^{10}$. The moral panics surrounding ritual murder ${ }^{11}$ and the criminalization of witchcraft ${ }^{12}$ have proven especially illuminating regarding the clashes between colonial and African worldviews, whilst juvenile delinquency has been fruitfully investigated as a marker of late-colonial anxiety and the perceived detrimental impact of capitalism, poverty and urbanization on African societies ${ }^{13}$. Two excellent historiographical reviews on law, crime and punishment in colonial Africa have recently been provided by fieldleading scholars Richard Roberts and Richard Waller ${ }^{14}$ delineating the development of colonial criminal and legal history. The majority of the literature however focuses British and French colonies, and greater analysis of Belgian, Portuguese and Italian territories, as well as Ottoman influences in North Africa, would deepen our knowledge and enable better comparative analyses. One welcome development has been the recent growth of analyses of Islamic law, although these have often focused on "civil" more than "criminal" offences ${ }^{15}$.

In terms of sources, scholars working in African pre-colonial and colonial history can only look on with envy and covetousness at the range and depth of sources available through projects such as the Old Bailey Online and the Digital Panopticon ${ }^{16}$. National archives in African countries and former imperial metropoles do hold extensive, if not always detailed, records on colonial law, crime and punishment. For British colonial Africa, for example, colonies produced annual police, prisons, and legal reports, and court records (sometimes including trial transcripts) have often been preserved, whilst administrative officers who sat as judges in District Court sometimes recounted their cases and findings. Colonies also produced annual

\footnotetext{
Ranger (1983).

$5 \quad$ Chanock (1985); Moore (1986); Mann and Roberts (1991); Merry (1991); Mamdani (1996); Benton (2002); Roberts (2005).

$6 \quad$ Rotberg (1971); Crummey (1986); Anderson (1993, 2018).

7 Akyeampong (1996); Willis (2005).

8 White (1992).

9 Vaughan (1983); McCullock (1995).

10 Bernault (2006).

11 Murray and Sanders (2006); Pratten (2007).

12 Gray (2001); Luongo (2011).

13 Campbell (2002); Fouchard (2010); George (2014).

14 Roberts (2013); Waller, 2014).

15 Jeppie et al. (2010).

16 See https://www.oldbaileyonline.org/ and https://www.digitalpanopticon.org/.
} 
"Blue Books" which collated government statistics and reports. Postcolonial holdings however tend to be much patchier, with post-independence governments failing to appropriately archive their departmental records, and many collections lack necessary cataloguing and preservation, particularly in district archives. There is however a wider range of materials available for the study of African crime and criminal justice than is often realised, and much of it remains - if not pristine - then at least untouched by historians' hands and ripe for analysis. Witness testimonies and confessions from murder trial case files have provided fascinating insights into the socio-economic tensions which strained African families and communities ${ }^{17}$. Colonial statistics offer under-explored possibilities for comparative, quantitative research. Regional district archives and missionary records in particular offer profitable avenues for exploring local histories of crime and customary law, as do private papers of legal officials, whilst vernacular print cultures, proverbs and oral traditions can offer useful insights into local understandings of social transgression and its sanctioning.

Over the past few years there has been a particular growth in studies of colonial punishment and state violence in Africa. Colonial states introduced metropolitan criminal justice systems into Africa that clashed with local restorative notions of punishment and often legitimized penal sanctions that were no longer acceptable in metropolitan Europe itself, such as flogging and public execution. Colonial penal systems in Africa quickly became characterized by a focus on didactic deterrence and a maintenance of law and order ${ }^{18}$, whilst policing was far more by coercion than consent $^{19}$. Scholars have highlighted how, despite colonial rhetoric of penal reform and modernization, violence remained central to colonial penality, with continued use of the death penalty ${ }^{20}$ and corporal punishment ${ }^{21}$. Prisons differed from the Western penitentiary model in their conscious strategy to constrain bodies rather than discipline minds ${ }^{22}$. Further research however is required on non-custodial forms of punishment, such as fines and compensation, the exiling of political opponents, and the use of collective punishments in the face of anti-colonial unrest and rebellion. Looking towards imperial records, in Britain the recently declassified Hanslope "migrated archive" 23 offers a treasure trove of information on the late colonial state's attempts to retain control over its increasingly recalcitrant subjects. These records have already helped rewrite the history of state violence during states of emergency, particularly during the Mau Mau rebellion in Kenya, demonstrating the full extent of the atrocities and violence committed by British forces and their African allies during military campaigns, forced villagization and detention camps ${ }^{24}$. The migrated archive however also contains detailed records on late colonial policing and state surveillance, including Special Branch records on alleged political subversion, sedition, and communist interference, which are yet to be fully explored. French

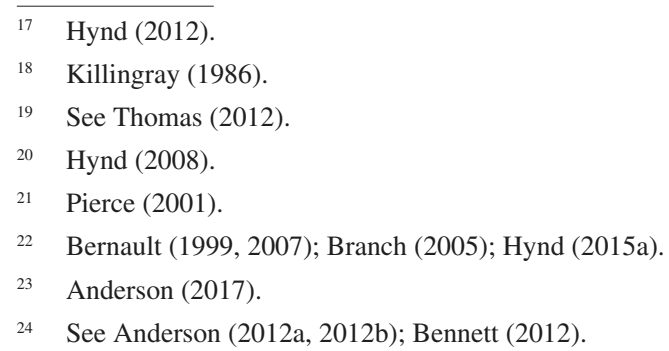


colonial violence is also coming under renewed historical scrutiny, with recent analyses of the Algerian war of independence highlighting the abuse and torture of prisoners and detainees ${ }^{25}$, and the extreme violence of colonial policing and paramilitary techniques ${ }^{26}$. Incidentally, it would be beneficial for studies of late colonial violence (both judicial and extra-judicial) to move beyond a focus on Mau Mau and Algeria, and to develop our understandings of other, more under-researched, decolonization struggles and associated rights-abuses, such as in those in Malawi ${ }^{27}$ and Cameroon.

There is still a need for broader contextual studies of penality rather than just punishment, and for research that illuminates the relationship between different forms of judicial and extra-judicial violence in colonies ${ }^{28}$ : between capital punishment and punitive expeditions against rebellious tribes; between flogging in prisons and on plantations; and between prison labour, forced labour, "unfree" labour and slavery more broadly ${ }^{29}$. As the 2016 "Crime and Punishment in Africa" conference at the University of Florida noted, there is a need for studies that "move beyond lists of crimes and their punishments to look at what takes place in prisons in both colonial and postcolonial Africa, and examines the conduct of warders and prisoners alike" ${ }^{130}$. Jocelyn Alexander's exemplary research on the history of political imprisonment in Zimbabwe draws on oral history, archives and political memoirs to demonstrate how detention camps could serve as spaces of practical and imaginative exercises in self-government and state-making, rather than just being spaces of repression ${ }^{31}$. The role of African professionals in colonial and postcolonial criminal justice systems is certainly deserving of greater investigation. Historians have begun to interrogate the experiences of African interpreters, clerks, judges and lawyers ${ }^{32}$ to explore the power and tactical agency they exerted within colonial court structures. Katherine BruceLockhart's doctoral research on the Ugandan prison service is an excellent example of the value of this professional focus. Based in part on extensive interviews with former prison officers it highlights how prison staff constructed a distinct professional ethos that helped to advocate for penal modernization in the colonial era and to avoid prisons becoming sites of torture and extreme violence under Idi Amin's authoritarian regime $^{33}$. Oral history, with its potential for recovering/uncovering African voices that are otherwise absent in the archive, is certainly one research methodology that should be more fully utilised in researching law and crime in the continent for the colonial and independence era.

One area where there has been a striking growth in research since the late 1990s has been on gendered experiences of crime and criminal justice. Early studies explored both the restrictions and possibilities for agency afforded to African women

\footnotetext{
25 Branche $(2001,2014)$.

26 Thomas (2011); Evans (2012); Klose (2012).

27 McCracken (2011).

28 See Alexander and Kynoch (2011).

29 Hynd (2015b).

30 See Leedy and White (forthcoming).

31 Alexander (2011).

32 Lawrance et al. (2006); Ibhawoh (2013); Karekwaivanane (2016).

33 Bruce-Lockhart (forthcoming).
} 
within colonial legal systems ${ }^{34}$. Inspired by the cultural turn and feminist histories, scholars subsequently explored women's experiences of colonial exploitation and empowerment. Hodgson and McCurdy's edited volume on "wicked women" in particular has inspired a subsequent generation of scholars to use histories of crime and deviance to explore shifting notions of gender ${ }^{35}$. Colonial attempts to manage or control female sexual activity have dominated much of the literature, which has focused on marriage disputes and adultery ${ }^{36}$, prostitution ${ }^{37}$, illicit sex ${ }^{38}$, coercive marriage ${ }^{39}$ and rape ${ }^{40}$. Others have focused on linkages between new forms of masculinity and criminal cultures ${ }^{41}$, or on female violent crime ${ }^{42}$. A burgeoning literature has also been generated in recent years on African homosexualities, tracing the criminalization of homosexual practices and the crimes committed against Africa's LGBTQ+ communities, partly in response to recent attacks on LGBTQ+ persons and their human rights by both religious and political bodies ${ }^{43}$.

Other productive avenues for future research include a focus on the social meaning of crimes rather than just their punishment. There has been a shift in recent historiography away from the strictly empirical, administrative perspectives of colonial history towards a more socio-cultural perspective on law and criminality. Recent studies have productively focused on the quotidian realities and everyday experiences of law, crime and social (dis)order in Africa, giving greater space to personal narratives. This has been driven in part by the growth of African Studies as a discipline, and by a shift in methodology towards increasingly inter-disciplinary analyses of law, crime and punishment. Inter-disciplinary conferences have provided constructive venues in recent years for the discussion of issues of both historical and contemporary concern, such as domestic violence ${ }^{44}$, forced marriage ${ }^{45}$ and law and social order ${ }^{46}$. The input of anthropologists and historical anthropology has greatly enhanced our knowledge of local African understandings of what constitutes a "crime" and suitable punishment, and how these often clash with global, Westernised peno-legal practice. In his recent, post-humously published, study of Nigerian organised crime, Stephen Ellis highlights the affective and metaphysical dimensions of criminality, and how understanding the spirit world and its impact on an individual's prosperity is a prerequisite for studying crime in that country ${ }^{47}$.

\footnotetext{
Hay and Wright (1982).

35 Hodgson and McCurdy (2001).

36 Shadle (2006); Burrill (2015).

37 White (1992).

38 Aderinto (2015).

39 Bunting et al. (2016).

40 Thornberry (2016).

41 Glazer (2000).

42 Zimudzi (2004).

43 Epprecht (2013).

44 Roberts et al. (2010).

45 Bunting et al. (2016).

46 Karekwaivanane and Cooper-Knock (2016).

47 Ellis (2016).
} 
The literature on ideas of crime and criminality in South Africa is particularly rich ${ }^{48}$. Contemporary studies of African criminality have increasingly been informed by socio-legal perspectives and by the development of African criminology as a field of inquiry. Studies of policing in particular have benefited from this approach, with growing investigation of the relationship between formal and informal institutions of policing ${ }^{49}$, of community policing and vigilantism ${ }^{50}$, and of police violence ${ }^{51}$. Olly Owen's excellent ethnographic research on the Nigerian police highlights how the violence, corruption and negligence that typifies interactions with the police may be less signs of officer's power than of their own attempts to cope with their lack of power within the hierarchical and paramilitarized police infrastructure ${ }^{52}$, and has recently been influencing police training reform in Nigeria.

Perhaps the most exciting spaces for future research however lie in relationships between states, societies and crime the postcolonial and contemporary eras. The 1970-80s - often referred to as the "decades of the dictators" - were in many parts of Africa years of economic downturn and state collapse, the rise of authoritarianism and the abjection of Western-style "modernity". As a result, they were also a time of burgeoning criminality and a breakdown in any semblance of a "rule of law". Conflict, reduced budgets and a lack of political will has meant that state archives have in many cases either seen significant tranches of their holdings destroyed, poorly preserved, or simply never deposited by the relevant government departments ${ }^{53}$. The political transition to majority rule with the end of apartheid in South Africa was infamously accompanied by the destruction of incriminating government document ${ }^{54}$. However, private archives and family papers, university research deposits law societies, and newspapers all contain valuable information on patterns of crime, whilst district archives can retain surprising amounts of holdings from state surveillance reports on actions classified as "political crimes" and opposition to the state. From an international perspective, local and international NGO reports from groups such as Amnesty International, Human Rights Watch and various UN bodies, provide detailed evidence on patterns of crime judicial and extra-judicial punishments across Africa. Recent research on Uganda in particular has highlighted the possibilities posed by such materials. Alicia Decker's compelling account of women's experiences during Idi Amin's reign in Uganda in the 1970s draws on archival and oral histories to demonstrate the how women socially navigated the violence and criminality of Amin's regime, and how they sought to locate the family members who had been detained or "disappeared" by the state, without getting arrested themselves ${ }^{55}$.

There is a pressing need for more research on postcolonial punishment, both judicial, and extra-judicial. Postcolonial states have often been characterized by the capricious application of the rule of the law, shown in many countries by the use

\footnotetext{
48 See e.g. Kynoch (2013), Gillespie (2014).

49 Cooper-Knock (2016).

50 Smith (2015).

51 Steinberg (2014).

52 Owen (2016).

53 Ellis (2002).

54 Harris (2000).

55 Decker (2014).
} 
of widespread detention and imprisonment as punishments in and of themselves. Political detainees have written powerfully about their experiences ${ }^{56}$ and now scholarly investigation of political detention and imprisonment is effectively highlighting the extent of abuses committed and resistance offered ${ }^{57}$. Further study of imprisonment as a whole is required however, as is study of both corporal and capital punishment ${ }^{58}$ and other forms of violence against citizens by state officials or proxies. Has there been a "carceral archipelago" 59 in Africa, beyond perhaps the example of apartheid South Africa? Theoretically speaking, there is further debate to be had on to what extent Eurocentric notions of punishment offered by scholars like Foucault and Garland apply in an African context ${ }^{60}$. In terms of criminal justice, the accountability borne respectively by the legacies of colonialism and postcolonial politics requires greater elucidation in relation to the abrogation of the rule of law in some states. Do states require full control of their courts and judges to routinely imprison their enemies? What can investigating rates of acquittal, appeal and suspended sentences tell scholars about the nature of justice and punishment in Africa?

Focusing on the contemporary era, there are perhaps two key pathways for research on crime and law: firstly in relation to the impact of conflict, and secondly to the impact of democratization and economic liberalization, the parallel processes which have shaped the African continent since the 1990s. The relationship between war and crime offers many productive avenues of investigation for understanding the development of criminal cultures and networks in many regions, particularly in today's globalized world. War creates conditions for new forms of crime as people seek to survive, or even thrive, in dangerous conditions. Samuel Daly's innovative doctoral research on the legal system in Biafra during the Nigerian civil war 1967-70 accesses previously ignored documentation from the short-lived secessionist Biafran government to compellingly highlight the strategies of "survival by deception" that ordinary Biafrans embarked upon to secure their and their families' access to resources and protection ${ }^{61}$, but also shows how these strategies provided templates for the criminal cultures which have plagued Nigeria in recent years. In the postCold War era, scholars have noted the linkages between so-called "new wars", which swept countries like Sierra Leone and Liberia, and global or regional criminal activities ${ }^{62}$. Whilst it is historically disputable whether there is anything "new" about these linkages, the theory of "resource curses" and "greed" driving conflict, with the criminal extraction and sale of highly lootable resources like coltan and "blood diamonds" fuelling extremely violent and protracted conflicts, has proven highly influential ${ }^{63}$. The links between criminal enterprises - including armed robbery, drug smuggling, and arms trading - and terrorist organizations like Boko Haram and AQIM in West Africa and Al-Shabaab in Somalia also require greater scholarly investigation.

\footnotetext{
56 See First (1965); Soyinka (1972); Mapanje (2011).

57 See Alexander (2011).

58 Karimunda (2014).

59 Foucault (1975).

60 Steinberg (2016b).

${ }_{61}$ Daly (2017).

62 Kaldor (1999).

63 See Collier and Hoeffler (2002).
} 
Recent developments in international law have driven new research into war crimes and crimes against humanity, particularly in relation to sex- and gender-based violence, with major ongoing research focusing on the practice of forced marriage and sexual slavery in African conflicts ${ }^{64}$, and the impact of conflict-related violence on peace-time domestic and sexual violence ${ }^{65}$. Scholars are also beginning to unpack the relationship between transitional justice, human rights and criminal justice in post-conflict spaces, highlighting how social accountability, trust in the rule of law and access to tangible justice - or at a least belief in the possibility of that justice can be crucial components in peace-building processes ${ }^{66}$. They have also highlighted how African "traditional justice", such as gacaca courts in Rwanda, can contribute to transitional justice ${ }^{67}$. Others have highlighted the contentious place which Africa and ideas of Africa occupy in international criminal and humanitarian law, particularly following the International Criminal Court's unifocal targeting of African offenders ${ }^{68}$. Such discussions of rights and justice however raise the question of exactly what is meant by those terms among by African populations. The concept of "justice" itself has been a largely neglected topic and requires further study ${ }^{69}$.

Turning to peace-time developments in law and crime, there is an academic consensus that there has been a "criminalization of the state" across many parts of Africa since the independence-era, which has been deepened by the spread of neoliberal economic regimes and democratization ${ }^{70}$. John and Jean Comaroff posit that rising criminality in the postcolony is part of a dialectic of law and dis/order, framed by deregulation and new modes of mediating human transactions: criminal violence here does not so much repudiate the rule of law or the licit operation of the market, as appropriate it ${ }^{71}$. With contemporary global interest in the rise of kleptocratic politics, there is a need for more, and better, historicization of this erosion of the line between the political and the criminal across Africa. Ellis and Pierce have effectively shown how this can be undertaken ${ }^{72}$, with their historical and anthropological analyses of corruption in Nigeria, but future research should also focus on related issues of fraud, bribery and economic crimes, youth militias and election violence, highlighting the crimes committed by Africa's "Big Men" as well as ordinary citizens. More broadly, the inter-disciplinary 2016 Carter conference on crime and punishment in Africa at the University of Florida raised three important avenues for future research. Firstly, it called for greater analysis of the transnational dimensions of crime, suggesting scholars look at crimes such as poaching and smuggling ${ }^{73}$ that involve trade across borders and are illegal in different, transnational domains. Further analysis is also

\footnotetext{
64 Bunting (2012).

65 Medie (2013); Porter (2016).

66 See Allen and MacDonald (2015).

67 Clark (2010).

68 Clarke (2009); Allen (2013).

69 Johnson and Karekwaivanane (forthcoming).

70 Bayart et al. (1999).

71 Comaroff and Comaroff (2006).

72 Ellis (2016); Pierce (2016).

73 Scheele (2012).
} 
required on the development of transnational and global dimensions of African crime, particularly in relation to the international drugs trade ${ }^{74}$ and modern forms of slavery and human trafficking ${ }^{75}$, but also criminal practices that take advantage of globalized networks of communication and information like the infamous Nigerian "419 scam" emails. Secondly, it noted that historians should investigate the processes by which customary practices, such as subsistence hunting, same-sex relations, or the use of natural stimulants like khat, become criminalized in a modern state. This also highlights the issue of "quasi-legality" and the shifting definitions and boundaries of crime in law and social practice. Thirdly, the question was raised as to how to study actions that are criminal according to both domestic and international laws but which routinely go unpunished, such as pogroms in Rwanda or farm invasions in Zimbabwe. This reflects John and Jean Comaroff's highlighting of the need to study the "zones of ambiguity between the presence and absence of law" that have emerged in the postcolony ${ }^{76}$. Another area of pressing future research would be the threats posed to the environment and sustainable development across the continent by criminal and illicit activities.

Overall, perhaps the most productive shift in terms of the development of African literature however would be a move away from seeing Africa as a "dark continent" or an exceptional space and towards the greater integration of Africa and Africanist scholars into broader global histories of crime and criminal justice. Africa is increasingly being read into histories colonial penality and the "coercive networks of empire" ${ }^{17}$ ), as recent studies of murder trials ${ }^{78}$, deviance ${ }^{79}$ and convict labour ${ }^{80}$ show, whilst Clare Anderson's "Carceral Archipelago" project fruitfully includes Africa in its analysis of the relationships and circulations between convict transportation, penal colonies, labour migration, and carceral spaces more broadly ${ }^{81}$. In future, it would be welcome to move beyond thinking of Africa as a space of the criminal "Other" or of penal primitivism, and to explore the differences and similarities which mark its treatments of crime and justice from those in Europe and elsewhere. The integration of Africa into the field of criminal history more broadly would be of benefit to both Africanists and criminal historians.

Stacey Hynd

Senior Lecturer in History University of Exeter (UK) s.hynd@exeter.ac.uk

\footnotetext{
74 See Carrier and Klantschnig (2012).

75 Quirk (2011); Lawrance and Roberts (2012).

76 Comaroff and Comaroff (2006).

77 Sherman (2009).

78 Wiener (2007).

79 Jackson and Manktelow (2015).

80 de Vito and Lichtenstein (2015).

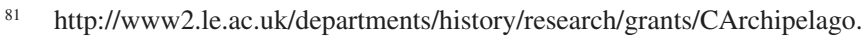




\section{BIBLIOGRAPHY}

Aderinto, S. (2015) When sex threatened the state: illicit sexuality, nationalism and politics in colonial Nigeria, 1900-58, Chicago: University of Illinois Press.

Akyeampong, E. (1996) Drink, power and cultural change: a social history of alcohol in Ghana, c.1800 to recent times, Oxford: Oxford University Press.

Alexander, J. (2011) Nationalism and self-government in Rhodesian detention: Gonakudzingwa, 1964-74, Journal of Southern African Studies, 37, 3, p.551-569.

Alexander, J. and Kynoch, G. (Eds.) (2011) Special issue: histories and legacies of punishment in southern Africa, Journal of Southern African Studies, 37, 3.

Allen, T. (2013) Trial justice: the International Criminal Court and the Lord's Resistance Army, London: Zed Books.

Allen, T. and MacDonald, A. (2015) Social accountabilities in war zones - confronting local realities of law and justice, International Journal on Minority and Group Rights, 22, 3, p.279-308.

Anderson, D.M. (1993) Black mischief: crime, protest and resistance in colonial Kenya, The Historical Journal, 36, 4, p.851-877.

Anderson, D.M. (2012a) Guilty secrets: deceit, denial and the discovery of Kenya's "migrated archive", History Workshop Journal, 80, 3, p.142-160.

Anderson, D.M. (2012b) British abuse and torture in Kenya's counter-insurgency, 1952-60, Small Wars \& Insurgencies, 23, 4, p.700-719.

Anderson, D.M. (2018) Resistance, protest and rebellion in colonial Kenya, 1890-1963, London: Routledge.

Bayart, J-F., Ellis, S. and Hibou, B. (1999) The criminalization of the state in Africa, Oxford: James Currey.

Bennett, H. (2012) Fighting the Mau Mau: the British army and counter-insurgency in the Kenyan emergency, Cambridge: Cambridge University Press.

Benton, L. (2002) Law and colonial cultures: legal regimes in world history, 1400-1900, Cambridge: Cambridge University Press.

Bernault, F. (Ed.) (1999) Enfermement, prison et châtiments en Afrique: du $19^{e}$ siècle à nos jours, Paris: Karthala.

Bernault, F. (2006) Body, power and sacrifice in equatorial Africa, Journal of African History, 47, 2, p.207-239.

Bernault, F. (2007) The shadow of rule: colonial power and modern punishment in Africa, in Dikötter, F. and Brown, I. (Eds.), Cultures of confinement: a history of the prison in Africa, Asia and Latin America, Ithaca: Cornell University Press, p.55-94.

Branch, D. (2005) Imprisonment and colonialism in Kenya: escaping the carceral archipelago, 1930-52, International Journal of African Historical Studies, 38, 2, p.239-266.

Branche, R. (2001) La torture et l'armée pendant la guerre d'Algérie, Paris: Gallimard.

Branche, R. (2014) Prisonniers du FLN, Paris: Payot.

Bruce-Lockhart, K. (2014) Unsound' minds and broken bodies: the detention of "hardcore" Mau Mau women at Kamiti and Gitamaya detention camps in Kenya, 1954-60, Journal of Eastern African Studies, 8, 3, p.590-608. 
Bruce-Lockhart, K. (2017) Imagining modernity in Uganda prison's service, 1945-79, PhD. Thesis, University of Cambridge.

Bunting, A. (2012) "Forced marriage" in conflict situations: researching and prosecuting old harms and new crimes, Canadian Journal of Human Rights, 1, 1, p.165-186.

Bunting, A., Lawrance, B.N. and Roberts, R.L. (Eds.) (2016) Marriage by force? Contestation over consent and coercion in Africa, Athens, $\mathrm{OH}$ : Ohio University Press.

Burrill, E.S. (2015) States of marriage: gender, justice and rights in colonial Mali, Athens, $\mathrm{OH}$ : Ohio University Press.

Campbell, C. (2012) Juvenile delinquency in colonial Kenya, 1900-39, The Historical Journal, 45,1, p.129-151.

Carrier, N. and Klantschnig, G. (2012) Africa and the war on drugs, London: Zed Books.

Chanock, M. (1985) Law, custom and social order: the colonial experience in Malawi and Zambia, Cambridge: Cambridge University Press.

Clark, P. (2010) The gacaca courts and post-genocide justice and reconciliation in Rwanda: justice without lawyers, Cambridge: Cambridge University Press.

Clarke, K.M. (2009) Fictions of justice: the International Criminal Court and the challenge of legal pluralism in sub-Saharan Africa, Cambridge: Cambridge University Press.

Collier, P. and Hoeffler, A. (2002) Greed and grievance in civil war, World Bank policy research working paper 2355 .

Comaroff, J.L. and Comaroff, J. (2006) Law and disorder the postcolony: an introduction, in Comaroff, J.L. and Comaroff, J. (Eds.), Law and Disorder in the postcolony, Chicago: University of Chicago Press, p.1-56.

Cooper-Knock, S.J. (2016) Behind closed gates: everyday policing in Durban, South Africa, Africa, 86, 1, p.98-121.

Crummey, D. (1986) Banditry, rebellion and social protest in Africa, London: James Currey.

Daly, S.F.C. (2017) The survival con: fraud and forgery in the republic of Biafra, Journal of African History, 58, 1, p.129-44.

Danquah, J.B. (1928) Akan laws and customs and the Akim Abuakwa constitution, London: Routledge \& Sons.

Decker, A.C. (2014) In Amin's shadow: women, gender and militarism in Uganda, Athens, $\mathrm{OH}$ : Ohio University Press.

De Vito, C.G. and Lichtenstein, A. (Eds.) (2015) Global convict labour, Leiden: Brill.

Ellis, S. (2002) Writing histories of contemporary Africa, Journal of African History, 43, 1, p.1-26.

Ellis, S. (2016) This present darkness: a history of Nigerian organised crime, London: Hurst.

Epprecht, M. (2013) Sexuality and social justice in Africa: rethinking homophobia and forging resistance, London: Zed Books.

Evans, M. (2012) Algeria: France's undeclared war, Oxford: Oxford University Press.

First, R. (1965) 117 days, London: Bloomsbury.

Fourchard, L. (2010) The making of the juvenile delinquent in Nigeria and South Africa, 193070, History Compass, 8, 2, p.129-142.

Foucault, M. (1975) Surveiller et punir: naissance de la prison, Paris, Gallimard.

George, A. (2014) Making modern girls: a history of girlhood, labour and social development in twentieth-century colonial Lagos, Athens, OH.: Ohio University Press. 
Gillespie, K. (2014) Murder and the whole city, Anthropology South Africa, 37, 3/4, p.203-212. Glazer, C. (2000) Bo-Tsotsi: the youth gangs of Soweto, 1935-76, Oxford: James Currey.

Gluckman, M. (1955) The judicial process among the Barotse of Northern Rhodesia, Manchester: Manchester University Press.

Gray, N. (2001) Witches, oracles and colonial law: evolving anti-witchcraft practices in Ghana, 1927-32, International Journal of African Historical Studies, 34, 2, p.339-363.

Harris, V. (2000) "They should have destroyed more": the destruction of public records by the South African state in the final years of apartheid, 1990-94, Transformation, 40, p.29-56.

Hay, M.J. and Wright, M. (Eds.) (1982) African women and the law: historical perspectives, Boston: Boston University Press.

Hodgson, D., and McCurdy, S. (Eds.) (2001)"Wicked" women and the reconfiguration of gender in Africa, Portsmouth, NH: Heinemann.

Hynd, S. (2008) Killing the condemned: the practice and process of capital punishment in British Africa c.1900-50, Journal of African History, 49, 2, p.403-418.

Hynd, S. (2012) Murder and mercy: capital punishment in colonial Kenya, ca 1909-1956, International Journal of African Historical Studies, 45, 1, p.81-101.

Hynd, S. (2015a) “...a Weapon of immense value”? Convict labour in British colonial Africa, c.1850-1950s', in de Vito, C. and Liechtenstein, A. (Eds.), Global Convict Labour, Leiden: Brill, p. 249-272.

Hynd, S. (2015b) "Insufficiently cruel" or "simply inefficient"? Discipline, punishment and reform in the Gold Coast prison system, Ghana c. 1850-1957, in Miller, V. and Campbell, J. (Eds.), Transnational Penal Cultures: New Perspectives on Discipline, Punishment and Desistance, London: Routledge, p.19-35.

Ibhawoh, B. (2013) Imperial justice: Africans in empire's court, Oxford: Oxford University Press.

Jackson, W. and Manktelow, E.J. (Eds.) (2015) Subverting empire: deviance and disorder in the British colonial world, London: Palgrave Macmillan.

Jeppie, S., Moosa, E. and Roberts, R. (Eds.) (2010) Muslim family law in sub-saharan Africa: colonial legacies and postcolonial challenges, Amsterdam: Amsterdam University Press.

Johnson, J. and Karekwaivanane, G.H. (Eds.) (forthcoming) Pursuing justice in Africa, London: Palgrave Macmillan.

Kaldor, M. (1999) New and old wars: organised violence in a global era, Stanford: Stanford University Press.

Karekwaivanane, G.H. (2016) Through the narrow door: narratives of the first generation of African lawyers in Zimbabwe, Africa, 86, 1, p.59-77.

Karekwaivanane, G.H. and Cooper-Knock, S.J. (2016) Part Issue: Law and Social Order in Africa, Africa, 86, 1.

Karimunda, A.M. (2014) The death penalty: the path towards abolition, London: Routledge.

Kenyatta, J. (1938) Facing Mt Kenya, London: Secker and Warburg.

Killingray, D. (1986) The Maintenance of Law and Order in British Colonial Africa, African Affairs, 85, 340, p.411-37.

Klose, F. (2012) Human rights in the shadow of colonial violence: the wars of independence in Kenya and Algeria, Philadelphia: University of Pennsylvania Press. 
Kynoch, G. (2013) Fear and alienation: narratives of crime and race in post-apartheid South Africa, Canadian Journal of African Studies, 47, 3, p.427-441.

Lawrance, B.N. and Roberts, R.L. (Eds.) (2012) Trafficking in the wake of slavery: law and the experience of women and children, Athens, $\mathrm{OH}$ : Ohio University Press.

Lawrance, B. N., Osborn, E. and Roberts, R.L. (Eds.) (2006) Intermediaries, interpreters and clerks: African employees in the making of empire, Cambridge: Cambridge University Press.

Leedy, T., and White, L. (Eds.) (forthcoming) Crime and punishment in Africa, special issue of African Studies Review.

Luongo, K. (2011) Witchcraft and colonial rule in Kenya, 1900-55, Cambridge: Cambridge University Press.

Mamdani, M. (1996) Citizen and subject: contemporary Africa and the legacy of late colonialism, Princeton: Princeton University Press.

Mann, K. and Roberts, R.L. (Eds.) (1991) Law in Colonial Africa, Portsmouth, NH.: Heinemann. Mapanje, J. (2011) And the crocodiles are hungry at night, Boulder, CO.: Lynne Reinner.

McCracken, J. (2011) In the shadow of Mau Mau: detainees and detention camps during Nyasaland's state of emergency, Journal of Southern African Studies, 37, 3, p.535-550.

McCullock, J. (1995) Colonial Psychiatry and the African Mind, Cambridge: Cambridge University Press.

Medie, P. (2013) Fighting gender-based violence: the women's movement and the enforcement of rape law in Liberia, African Affairs, 112, 448, p.377-397.

Merry, S.E. (1991) Law and colonialism, Law and Society Review, 25, 4, p.889-922.

Moore, S.F. (1986) Social facts and fabrications: customary law on Kilimanjaro, 1880-1980, New York: Cambridge University Press.

Murray, C. and Sanders, P. (2006) Medicine murder in colonial Lesotho: an anatomy of a moral crisis, Edinburgh: Edinburgh University Press.

Owen, O. (2016) Government properties: the Nigeria police force as total institution?, Africa, 86,1, p.37-58.

Pierce, S. (2001) Punishment and the political body: flogging and colonialism in Northern Nigeria, Interventions, 3, 2, p.206-221.

Pierce, S. (2016) Moral economies of corruption: state formation and political culture in Nigeria, Durham, NC: Duke University Press.

Porter, H. (2016) After rape: violence, justice and social harmony in Uganda, Cambridge: Cambridge University Press.

Pratten, D. (2007) The man-leopard murders: history and society in colonial Nigeria, Edinburgh: Edinburgh University Press.

Ranger, T. (1983) The invention of tradition in colonial Africa, in Hobsbawm, E. and Ranger, T. (Eds.), The invention of tradition, Cambridge: Cambridge University Press, p.211-262.

Rattray, R.S. (1929) Ashanti law and constitution, Oxford: Clarendon Press.

Roberts, R. (2013) Law, Crime and Punishment in Colonial Africa, in Parker, J. and Reid, R. (Eds.), Oxford Handbook of Modern African History, Oxford: Oxford University Press.

Roberts, R. (2005) Litigants and households: African disputes and colonial courts in French Soudan, 1895-1912, Portsmouth, NH: Heinemann. 
Roberts, R.L., Burrill, E.S. and Thornberry, E. (2010) Domestic violence and the law in colonial and postcolonial Africa, Athens, $\mathrm{OH}$ : Ohio University Press.

Rotberg, R.I. (Ed.) (1971), Rebellion in Black Africa, London: Oxford University Press.

Quirk, J. (2011) The anti-slavery project: from the slave trade to human trafficking, Philadelphia: University of Pennsylvania Press.

Scheele, J. (2012) Smugglers and saints of the Sahara: regional connectivity in the twentieth century, Cambridge: Cambridge University Press.

Shadle, B. (2006) Girl cases: marriage and colonialism in Gusiiland, Kenya, 1890-1970, Portsmouth, NH: Heinemann.

Sherman, T. (2009) Tensions of colonial punishment: perspectives on recent developments in the study of coercive networks in Africa, Asia and the Caribbean, History Compass, 7, 3, p.659-677.

Smith, N.R. (2015) Rejecting rights: vigilantism and violence in post-apartheid South Africa, Africa, 114, 456, p.341-360.

Soyinka, W. (1972) The man died: prison notes of Wole Soyinka, London: Africa Book Centre.

Steinberg, J. (2014) Policing, state power and the transition from apartheid to democracy: a new perspective', African Affairs, 113, 451, p.173-191.

Steinberg, J. (2016a) A man of good hope: one man's extraordinary journey from Mogadishu to Cape Town, London: Jonathan Cape.

Steinberg, J. (2016b) How well does theory travel? David Garland in the global south, Howard Journal of Criminal Justice, 55, 4, p.514-531.

Thomas, M. (2011) Colonial violence in Algeria and the distorted logic of state retribution: the Sétif uprising of 1945, Journal of Military History, 75, 1, p.125-157.

Thomas, M. (2012) Violence and Colonial Order: Police, Workers and Protest in the European Colonial Empires, 1918-40, Cambridge: Cambridge University Press.

Thornberry, E. (2016) Rape, race and respectability in a South African port city: East London, 1870-1927, Journal of Urban History, 42, 5, p.836-880.

Vaughan, M. (1983) Idioms of madness: Zomba lunatic asylum, Nyasaland, in the colonial period, Journal of Southern African Studies, 9, 2, p.218-238.

Waller, R. (2014) Crime and the law in Colonial Africa, Oxford Bibliographies, [On line] http://www.oxfordbibliographies.com/view/document/obo-9780199846733/obo9780199846733-0158.xml (last accessed 10 January 2017).

White, L. (1992) The comforts of home: prostitution in colonial Nairobi, Chicago: Chicago University Press.

Wiener, M.J. (2007) An empire on trial: race, murder and justice under British rule, 18701935, Cambridge: Cambridge University Press.

Willis, J. (2005) Drinking power: alcohol and history in Africa, History Compass, 3, 1, p.1-13.

Zimudzi, T. (2004) African women, violent crime and the criminal law in colonial Zimbabwe, 1900-52, Journal of Southern African Studies, 30, 3, p.499-517. 